Reform and Counterreform 


\section{Religion and Society 34}

\section{General Editors}

Luther Martin, University of Vermont

Jacques Waardenburg, University of Lausanne

Mouton de Gruyter

Berlin • New York 


\section{Reform and Counterreform}

Dialectics of the Word in Western Christianity since Luther

Edited by

John C. Hawley

Mouton de Gruyter

Berlin • New York 1994 
Mouton de Gruyter (formerly Mouton, The Hague)

is a Division of Walter de Gruyter \& Co., Berlin.

(2) Printed on acid-free paper which falls within the guidelines of the ANSI to ensure permanence and durability.

\section{Library of Congress Cataloging-in-Publication Data}

Reform and counterreform : dialectics of the Word in Western Christianity since Luther / edited by John C. Hawley.

p. $\quad \mathrm{cm} .-($ Religion and society ; 34$)$

Includes bibliographical references and index.

ISBN 3-11-014016-0 (alk. paper)

1. Civilization, Christian - History. 2. Christianity and literature. 3. Christian literature - History and criticism.

I. Hawley, John C. (John Charles), 1947- . II. Series: Religion and society ; 34 .

BR115.C5R44 1994

$270-\mathrm{dc} 20$

Reform and counterreform : dialectics of the word in Western christianity since Luther / ed. by John C. Hawley. - Berlin ; New York :

Mouton de Gruyter, 1994

(Religion and society ; 34)

ISBN 3-11-014016-0

NE: Hawley, John C. [Hrsg.]; GT

(C) Copyright 1994 by Walter de Gruyter \& Co., D-10785 Berlin

All rights reserved, including those of translation into foreign languages. No part of this book may be reproduced or transmitted in any form or by any means, electronic or mechanical, including photocopy, recording or any information storage and retrieval system, without permission in writing from the publisher.

Disk conversion and Printing: Arthur Collignon $\mathrm{GmbH}$, Berlin.

Binding: Lüderitz \& Bauer, Berlin.

Printed in Germany. 